after whom we name the species. The original specimens of this coral, with several others obtained from the Habbies-Howe conglomerate, having been kindly placed at the disposal of the above (R. E., jun.), a short note was communicated on the subject to the Royal Physical Society of Edinburgh*.

In the note in question, T. Peachii was referred to provisionally as a species of Alveolites, with the remark, "if it is an Alveolite it is even finer in texture than the very fine Carboniferous species $A$. depressa, Flem."

Form. and Loc. In pebbles of Silurian limestone contained in the Old Red Standstone conglomerates of Habbies Howe, Pentland Hills, near Edinburgh.

Collected by, and in the cabinet of, Messrs. Brown, Henderson, and R. Etheridge, jun.; also coll. Geol. Surv. Scotl. Mus. Sci. and Art, Edinb., collected by Mr. J. Bennie.

\title{
XXII.-Description of an apparently new Species of
} Lamprocolius. By D. G. Elliot, F.R.S.E.

\section{Lamprocolius glaucovirens.}

A velvety black mark on the front extending between the eyes; top of head, occiput, and back of neck light metallic grass-green, which graduates into a cold dark blue upon the back. Auriculars metallic dark blue, similar to the back, but less brilliant, edged with coppery red. Throat and upper part of breast dark purplish blue, changing to dark greenish blue along the sides, where it touches the grass-green of the nape; this greenish blue colour also extending like a band across the upper part of the breast, enclosing the purplish-blue throat entirely. Centre of lower part of the breast bright metallic coppery red; abdomen and thighs cold greenish blue. Primaries have the outer webs shining bluish green, inner webs dark brown with a greenish gloss, the tips light metallic grass-green. Secondaries have their basal half metallic grassgreen like the tips of the primaries, then are crossed by a conspicuous broad velvety black bar; remainder cold dark blue, with the exception of the inner webs of the two innermost secondaries, which are light metallic grass-green like the basal portion. The coverts are metallic green, each feather tipped on the outer web with a velvety black spot, forming two rows across the wing. Shoulders metallic bronzy green.

$$
\text { - Loc. cit. pp. 50-52. }
$$


Axillaries dark cold prussian blue. Rump, upper and under tail coverts uniform shining light grass-green, without any bluish reflections. Tail has the base bluish green, and the apical portion for about an inch shining grass-green like the tail-coverts, without any purple reflections whatever; remaining portion bluish black, indistinctly barred on edge of outer web with shining bluish green. Total length 12 inches, wing $6 \frac{3}{8}$, tail $5 \frac{1}{2}$, culmen $\frac{3}{4}$, tarsus $1 \frac{1}{8}$.

I am indebted to M. A. Milne-Edwards for the opportunity of examining the bird here described, which belongs to the collection of the Paris Museum. The only species of the genus it can be compared with is the L. splendens, Vieill., with which it has apparently been confounded, but from which it differs greatly in its style of coloration as well as in size. The type of L. splendens is fortunately in the Paris Museum, in excellent preservation, without any, of its bright hues having faded or changed, as is proved by comparing it with other specimens of the same species in the gallery, more recently obtained. The general appearance of the $L$. glaucovirens is dark blue, relieved by the green of the top of the head and nape and also of the wing-coverts and shoulders. The back, throat, breast, secondaries, and tail are very differently coloured from those of $L$. splendens, and the two species when placed side by side are readily distinguished from each other. To enable it to be more easily recognized from its ally, I give a description of the prominent differences as exhibited by the two species.

Lamprocolius glaucovirens.

Throat and upper parts of breast dark purplish blue.

Under wing-coverts dark prussian blue. blue.

Abdomen and thighs greenish

Back dark blue.

Black bar on wings without purple lustre.

Upper and under tail-coverts uniform metallic light grass-green without any violet reflections.

Rectrices bluish green at base, then bluish black, and tipped with shining grass-green.

Length 12 inches, wing $6 \frac{3}{8}$, tail $5 \frac{1}{2}$, culmen $\frac{3}{4}$, tarsus $1 \frac{1}{8}$.
Lamprocolius splendens, Vieill.

Throat and upper part of breast bright violet.

Under wing-coverts violet-blue. let.

Abdomen and thighs bluish vio-

Back bright violet.

Black bar faint, overshadowed by violet reflections.

Upper and under tail-coverts dark violet-blue, with the tips bluish green.

Rectrices purple-violet, darkest in the centre of the feather, and tipped with purplish blue.

Length $11 \frac{1}{2}$ inches, wing $6 \frac{1}{4}$, tail 5, culmen $\frac{5}{8}$, tarsus $\frac{7}{8}$. (Type.)

The specimen which serves as the type of my description was sent to the Paris Museum from the Gaboon by M. Avinenc in $\mathbf{1 8 7 5 .}$ 


\section{$2 \mathrm{BHL}$ Biodiversity Heritage Library}

Elliot, Daniel Giraud. 1877. "XXII.-Description of an apparently new species of Lamprocolius." The Annals and magazine of natural history; zoology, botany, and geology 20, 169-170. https://doi.org/10.1080/00222937708682218.

View This Item Online: https://www.biodiversitylibrary.org/item/63588

DOI: https://doi.org/10.1080/00222937708682218

Permalink: https://www.biodiversitylibrary.org/partpdf/59742

\section{Holding Institution}

University of Toronto - Gerstein Science Information Centre

\section{Sponsored by}

University of Toronto

\section{Copyright \& Reuse}

Copyright Status: NOT_IN_COPYRIGHT

This document was created from content at the Biodiversity Heritage Library, the world's largest open access digital library for biodiversity literature and archives. Visit BHL at https://www.biodiversitylibrary.org. 